\title{
Wass Huba magyar származású amerikai dandártábornok
}

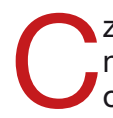

zegei Wass Huba', az Egyesült Államok haderejének magyar származású dandártábornoka és katonai teoretikusa, 1941. augusztus 13-án született Kolozsvárott. Apja szentegyedi és gróf czegei Wass Albert, földbirtokos, a Magyar Királyi Honvédségben szolgáló katonatiszt, író. A család a második világháborút követően Németországba, majd az USA-ba emigrált. A fiatal Wass Huba apjától lovagolni és vadászni is megtanult. 1964-ben évfolyamelsőként végezte el a West Point-i Katonai Akadémiát.

A tiszti iskola elvégzését követően ejtőernyős beosztásban kezdte meg katonai szolgálatát ${ }^{2}$. Két kiküldetés során századparancsnokként harcolt a vietnami háborúban, ahol a harcokban elért eredményeiért öt alkalommal érdemelte ki a Bronz Csillagot, majd az Ezüst Csillagot is. Kétéves szolgálata alatt két jelentősebb bevetésen vett részt, közvetlen tapasztalatot szerezve a helikopteres légimozgékony műveletek terén.

1. ábra. Wass Huba a vietnami háborúban, egy helikopter fedélzetén

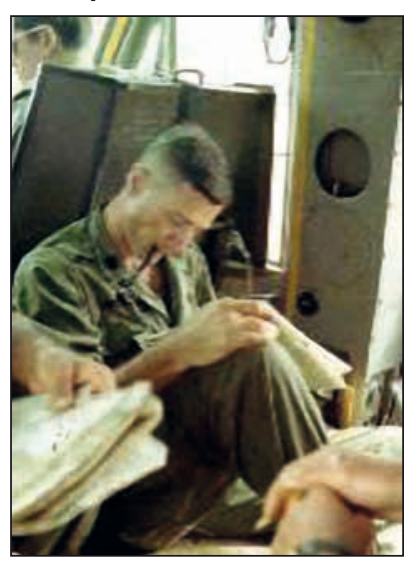

Hazatérve, a Harvard Egyetemen szerzett tudományos fokozatot, majd 1974-től a West Point-i Katonai Akadémián tanított ${ }^{3}$. 1979-től Wass Huba alezredesi rendfokozatban szolgált. Részt vett, majd 1979től vezető szerephez jutott az akadémián folyó doktrinális fejlesztő tevékenységben, így 1980-'82 között a légiföldi ütközet (Air-Land Battle) koncepciójának kidolgozásában $^{4}$. A Field Manual 100-5 „Hadmúveletek” szabályzat alapját képező új doktrína hatékony bevezetése érdekében 1983-ban, a kansasi Fort Leavenworth-
ÖSSZEFOGLALÁS: Czegei Wass Huba az Egyesült Államok haderejének magyar származású dandártábornoka és katonai teoretikusa. 1964-ben évfolyamelsőként végezte el a West Point-i Katonai Akadémiát. Harcolt a vietnami háborúban. 1974-tốl a West Point-i Katonai Akadémián tanított. 1979-tôl vezető szerephez jutott a légi-földi ütközet (Air-Land Battle) koncepciójának kidolgozásában, majd a Field Manual 100-5 „Hadmúveletek” szabályzat elkészítésében is. Fort Leavenworth-ben vezetésével létrehozták a Felsőfokú Katonai Tanulmányok Iskoláját (SAMS - School of Advanced Military Studies), amelynek parancsnoki teendôit is ellátta. Fő múve a társszerzőségével megjelent „Légi gépesített harc: a XXI. század aszimmetrikus manőverező hadviselése" címú könyv.

KULCSSZAVAK: Czegei Wass Huba, US Army, teoretikus, légi-földi ütközet, FM 100-5 szabályzat, School of Advanced Military Studies, légi gépesített harc

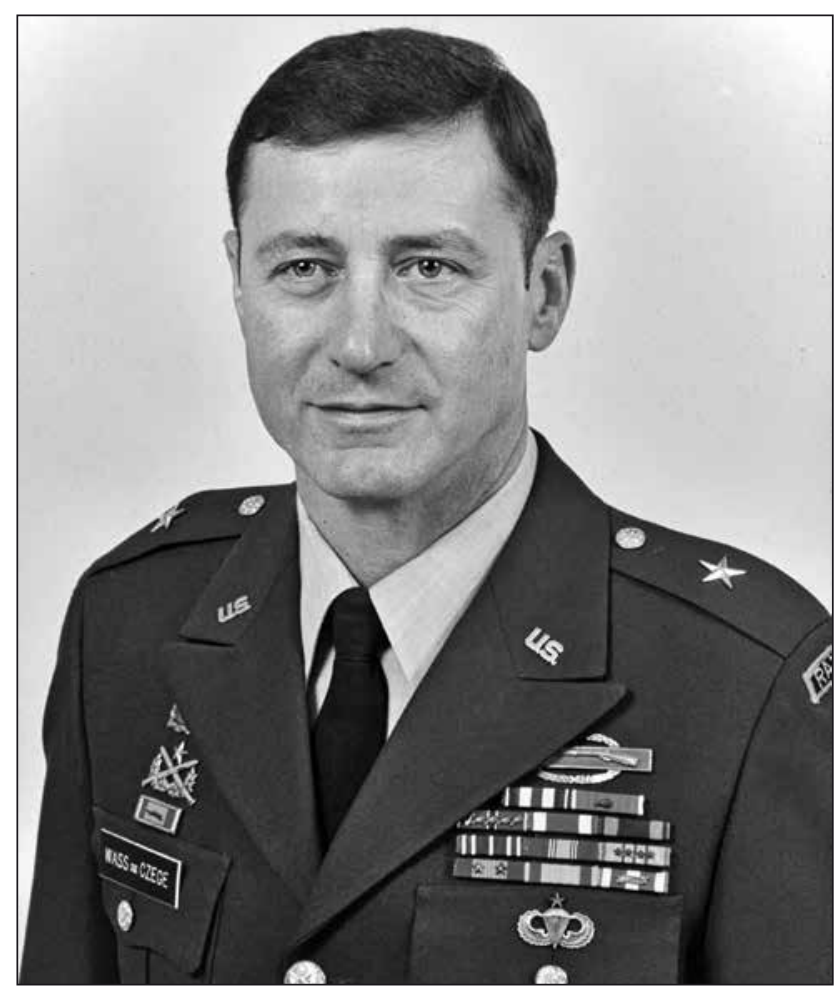

2. ábra. Wass Huba dandártábornok, a Fort Leavenworth-ben települö Felsőfokú Katonai Tanulmányok Iskolája (SAMS School of Advanced Military Studies) parancsnokaként. Az 1980-as évek elején kidolgozta a Field Manual 100-5 „Hadmúveletek" szabályzatot

ben vezetésével létrehoztak egy egyéves posztgraduális programot, a Felsőfokú Katonai Tanulmányok Iskoláját (SAMS - School of Advanced Military Studies), amelynek

ABSTRACT: Huba Wass de Czege is a Hungarian-born brigadier general and military theorist of the armed forces of the United States. In 1964, he graduated from the West Point Military Academy as the valedictorian. He fought in the Vietnam War. From 1974 he taught at the West Point Military Academy. From 1979 he played a prominent part in working out the concept of the AirLand Battle and then in preparation of the Field Manual 100-5, Operations too. The Army's School for Advanced Military Studies (SAMS) was established in Fort Leavenworth under his leadership and he also was the director of this institution. He was a co-author of the book Air-Mech-Strike: Asymmetric Maneuver Warfare for the 21st Century considered his masterwork.

KEY WORDS: Huba Wass de Czege, US Army, theorist, air-land battle, Field Manual 100-5, School for Advanced Military Studies, air mechanized strike

Mérnök őrnagy, Nemzeti Közszolgálati Egyetem KMDI/National University of Public Service KMDI, E-mail: hegedus.erno@hm.gov.hu, ORCID: 0000-0001-8457-5044 
1983-85 között a parancsnoki teendőit is ellátta ${ }^{5}$. Emellett Fort Leavenworth-ben az Egyesült Államok haderejének vezérkari iskoláján (General Staff College) Wass tábornok katonai felsővezetők generációit tanította.

A légi fölény előnyeit alkalmazó Air-Land Battle hadműveleti koncepció szerint a szövetségesek az ellenség hadműveleti mélységét, csapatösszevonásait a levegőből támadták volna, mintegy $300 \mathrm{~km}$ mélységig, helikopterekkel és csatarepülőgépekkel. A mélységben tevékenykedő közvetlen támogató légierő hatékonyan segíthette volna az ellenlökést végrehajtó páncéloskötelékek és az azokat támogató légideszantok harctevékenységét. Az ellenlökés céljából előrevont „tartalék lehet légi, vagy földi manőverező alakulat ... a szárazföldi haderő légi szállítású és légi rohamerői tartalékokként gyorsan képesek reagálni ... Amint azonban bevetették őket, mozgékonyságuk korlátozottá válik."6 (llyen módon az Air-Land Battle elméletet megfogalmazó szabályzat már 1982-ben kimondja azokat

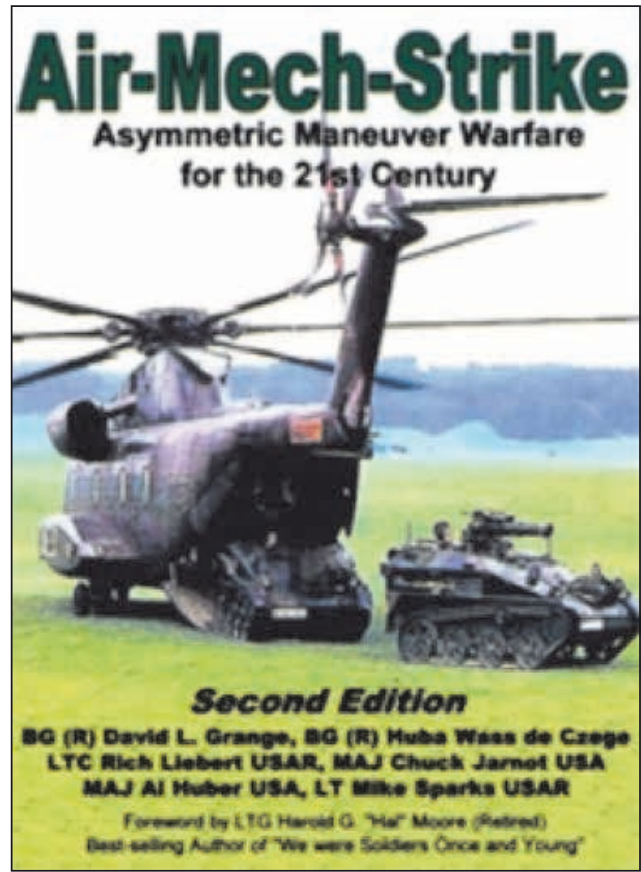

3. ábra. A Wass tábornok társszerzőségével megjelent "Légi gépesített harc: a XXI. század aszimmetrikus manőverező hadviselése" címú kötet a légi-földi ütközet (Air-Land Battle) koncepciójához köthető a haditechnikai korlátokat, amelynek megoldására később Wass Huba dandártábornok vezetésével létrehozták a következő hadműveleti elméletet megfogalmazó AirMechanisation Study Group-ot.) Az Air-Land Battle elmélet a mozgáscentrikus hadászati kultúra első markáns amerikai megjelenésének nevezhető. A szárazföldi erők és a légierő szoros együttműködésén alapuló védelmi koncepciót 1984-től a NATO is alkalmazta. A hidegháború végig az Air-Land Battle maradt az uralkodó hadműveleti elképzelés. 1986-ban volt egy frissítése (ami az alapokat érintetlenül hagyta). Wass Huba vezette az 1986-os kiadású FM 100-5-ös szabályzat szerkesztését is. „A Huba Wass de Czege által, a hetvenes években kifejlesztett Air-Land Battle koncepció gyakorlatilag a „blitzkrieg” („villámháború”) modernizált változata volt". ?

Wass Huba a '80-as évek végére az amerikai hadsereg dandártábornokává lépett elő. A 7. gyaloghadosztály 9 . könnyűgyalogos ezredében töltött be parancsnok-helyettesi beosztást. Később Brüsszelben, a NATO központban szolgált, a szövetséges haderők főparancsnokságán a NATO főtitkár és a szövetséges főparancsnok tanácsadója lett. Ebben a beosztásban az európai hagyományos fegyverzetű haderők (CFE - Conventional Armed Forces) csökkentésének végrehajtásait irányította. Ez idő táit felmerült Wass Huba dandártábornok magyarországi NATObeosztásba történő kinevezése is. A NATO európai főparancsnokának (Supreme Army Commander Europe SACREUR) kabinetfőnöki és főtanácsadói feladatát is betöltötte. Néhány évig a Fort Riley 1. hadosztály (Big Red One) parancsnok-helyettese is volt. Az Egyesült Államok hadseregének dandártábornokaként részt vett az 1991-es Sivatagi vihar hadművelet harcászati terveinek kidolgozásában is. A tábornok egyike azoknak a katonai teoretikusoknak, akik az öbölháborúban összeállították az iraki hadsereg megsemmisítésére vonatkozó terveket. Az Air-Land Battle koncepció - kiterjedt páncélos-kötelé- kek, a harcászati légierő és légideszant-csapatok együttműködésén alapuló hadművelet - elvei alapján vívták meg az 1991-es öbölháborút.

Wass Huba dandártábornok 1993-ban történt nyugállományba vonulását követően továbbra is aktív szereplője maradt a haderőben zajló tudományos munkának, amelynek ekkortól még több időt szentelhetett. A kilencvenes években aktívan részt vett az „Army After Next" programban, az amerikai haderő harcászati kísérleteinél volt tanácsadó (itt wargame szimulációt is alkalmaztak). Egészen 2010-ig tanácsadói szerepet töltött be a haderő kutatás-fejlesztési és szervezetfejlesztési ügynökségének, a DARPA-nak (Defense Advanced Research Projects Agency - Fejlett Technológiák Kutatási Hivatala) programjaiban is. Konzultánsi szerepkörben részt vett az Egyesült Államok Hadseregének Kiképzési és Doktrinális Központjának, a TRADOC-nak (U.S. Army Training and Doctrine Command) a munkájában is. Széles körü publikációs tevékenységet folytatott olyan katonai szakfolyóiratokban, mint az Armed Forces Journal, Military Review, Army Magazine, Small War Journal stb.

Wass dandártábornok munkássága a 2003. évi öbölháború időszakában kibontakozó hadműveleti elméletekre is jelentős hatással volt. Elméleti tevékenységének egyik meghatározó eleme a légideszantok gépesítésére vonatkozó elméletek kidolgozásában való részvétel. A pályafutása során leginkább a légideszantcsapatokhoz kötődő Wass tábornok, már a nyolcvanas évek elején a légideszant és könnyűfegyverzetű erők könnyű, kis méretű páncélozott eszközökkel való felszerelésén dolgozott ${ }^{8}$. Erre alapozva, a kilencvenes évek végén jelentősebb terjedelmű társszerzős publikációkat jelentetett meg a légi gépesítés témakörében. Az Air-Land Battle elméletet leíró FM-100-5 hadműveleti szabályzat ugyanis kimondja, hogy „amint bevetették a légideszantokat, mozgékonyságuk korlátozottá válik."9 Amerikai részről a második öbölháború idejére ismertté vált a légi gépesítés elmélete (Air Mechanisation Stryke - légi gépesített csapás). A légideszantcsapatok légi gépesítése alapelveinek kidolgozása érdekében a kilencvenes évektől működő légi gépesítés munkacsoport kötelékében (Air Mech Stryke Study Group - Airborne) elismert elméleti szakemberek - köztük Wass Huba dandártábornokok - tevékenykedtek. A munkacsoport légi gépesítés elveire vonatkozó eredményeit 2002ben a „Légi gépesített harc: a XXI. század aszimmetrikus manőverező hadviselése" címü könyvben adták közre. E tanulmány a kilencvenes években megkezdett elméleti munka, az ejtőernyős és helikopteres deszantok, illetve a légi úton szállított könnyűlövész csapatok gépesítéssel történő képességnövelésére, széles körű alkalmazása feltételeinek megteremtésére tesz javaslatot. Az elmélet hosszú távon - az ezredforduló után - a Stryker légiszállítású dandár koncepcióban vezetett konkrét haderő-fejlesztési eredményre. 


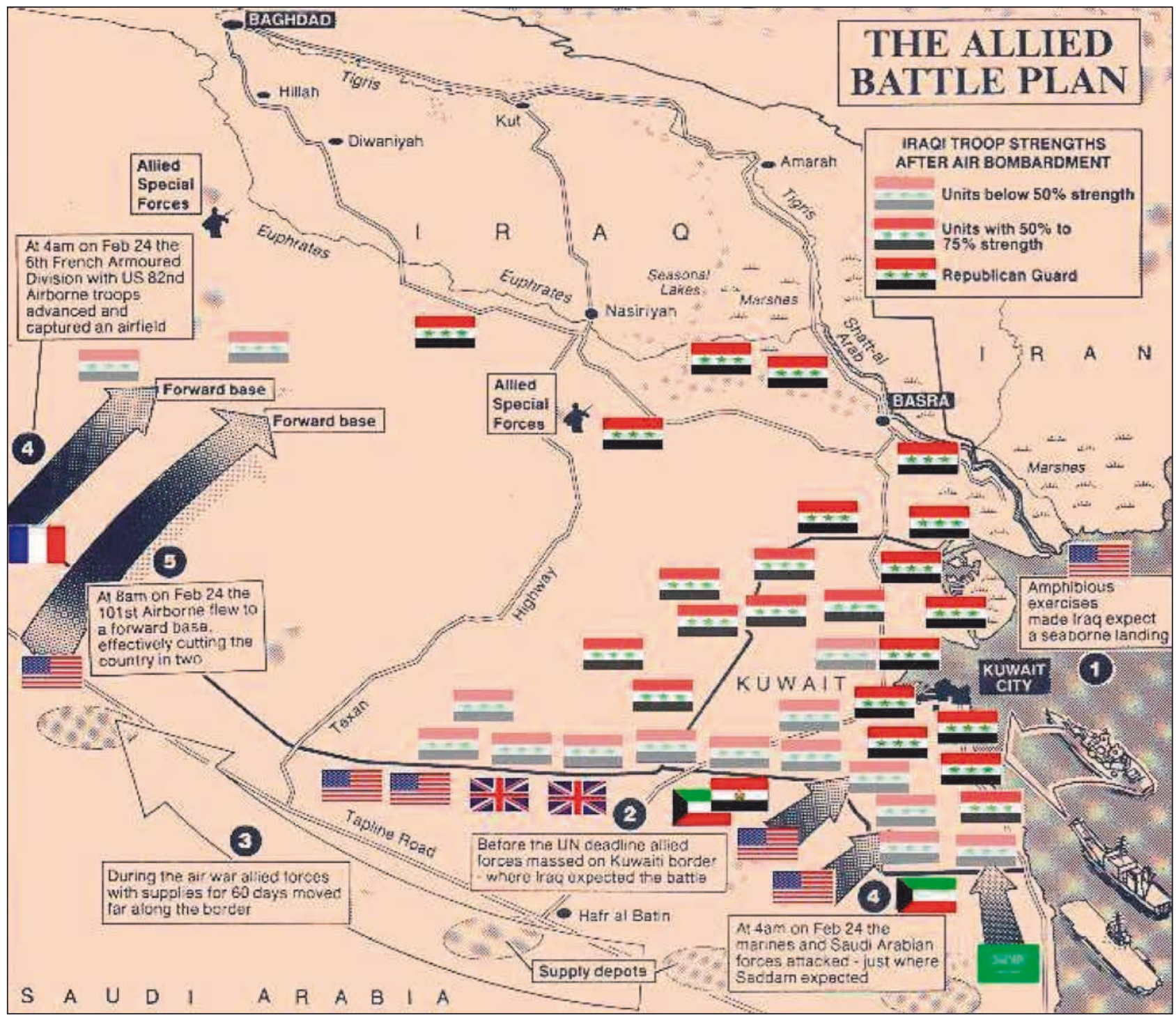

4. ábra. Az 1991. évi öbölháború szövetséges hadmúveleti terve, amelyet a Wass Huba tábornok által felállított vezérkari tanfolyamon képzett tábornokok terveztek meg és hajtottak végre, elsősorban az FM 100-5/1982 „Hadmúveletek” szabályzat alapján, a légi-földi ütközet (Air-Land Battle) hadmúveleti elv figyelembevételével

\section{FoRRÁSOK}

Brigadier General (Ret.) Huba Wass de Czege https://ssi. armywarcollege.edu/pubs/people.cfm?authorlD=64 [2018.09.26.];

Takaró Mihály (szerk.): Wass Albert titkai. Szabad Tér Kiadó - Czegei Wass Alapítvány, Budapest, 2006;

Huba Wass de Czege - Antullio J. Echevarria: Toward a Strategy of Positive Ends. Strategic Studies Institute, US Army War Collage, 2001. DOI: 10.21236/ ada397122;

Kiss Álmos Péter: Az Iraki Szabadság hadművelet sikerének háttere. Új Honvédségi Szemle 2003. évi 8. sz.;

Field Manual FM 100-5 Hadműveletek tábori kézikönyv. Magyar Honvédség Vezérkara, Budapest, 1997;

Kaplan, Fred: Force Majeure - What lies behind the military's victory in Iraq, 2003. 04. 10. http://www.slate. com/id/2081388/ [2018.09.26.];

Sándor Tamás: A Stryker dandár harccsoport: a gyorsan bevethető ütőképes haderő lehetőségei. Regiment, I. évf. 2005. 1. sz.

\section{JEGYZETEK}

1 Angol nyelvű irodalomban: Brigadier General Huba Wass de Czege.

2 Takaró Mihály (szerk.): Wass Albert titkai. Szabad Tér Kiadó

- Czegei Wass Alapítvány, Budapest, 2006. 181. o.

3 U. o. 190. és 194. o.

4 Huba Wass de Czege - Antullio J. Echevarria: Toward a Strategy of Positive Ends. Strategic Studies Institute, US Army War Collage, 2001. 5. o.

5 Kiss Álmos Péter: Az Iraki Szabadság hadművelet sikerének háttere. Új Honvédségi Szemle 2003. évi 8. sz. 3. és 4. o.

6 Field Manual FM 100-5 Hadműveletek tábori kézikönyv. Magyar Honvédség Vezérkara, Budapest, 1997. 191. o.

7 Kaplan, Fred: Force Majeure - What lies behind the military's victory in Iraq, 2003. 04. 10. http://www.slate.com/id/2081388/

8 Sándor Tamás: A Stryker dandár harccsoport: a gyorsan bevethetô ütőképes haderő lehetőségei. Regiment, I. évf. 2005. 1. sz.

9 Field Manual FM 100-5 Hadműveletek tábori kézikönyv. Magyar Honvédség Vezérkara, Budapest, 1997. 191. o. 